\title{
Antibacterial Activity of Flavonoids from Ethyl Acetate Extract of Milk Banana Peel (Musa x paradisiaca L.)
}

\author{
Wiwik Susanah Rita ${ }^{*}$, Ida Ayu Raka Astiti Asih', I Made Dira Swantara², Ni Luh Yuli Damayanti \\ ${ }^{1}$ Chemistry Department, Faculty of Mathematic and Natural Sciences Universitas Udayana Badung, Bali, Indonesia \\ ${ }^{2}$ Magister of Chemistry Department, Faculty of Mathematic and Natural Sciences, Universitas Udayana Badung, Bali, Indonesia
}

ARTICLE INFO

Article history:

Received October 8, 2020

Received in revised form May 27, 2021

Accepted June 3, 2021

\section{KEYWORDS:}

Flavonoids,

Antibacterial Activity,

Musa x paradisiaca L.,

Staphylococcus aureus,

Escherichia coli

\begin{abstract}
Infectious diseases caused by Staphylococcus aureus and Escherichia coli can be treated by milk banana peels (Musa $\times$ paradisiaca L.). This study aims to reveal the antibacterial activity of milk banana peel ethyl acetate extract against Staphylococcus aureus and Escherichia coli, and to identify their active compounds. Extraction was conducted by maceration at room temperature, followed by partition. Separation was carried out by column chromatography with mobile phase of chloroform: ethyl acetate $(7.5: 2.5)$ and stationary phase of silica gel 60 . Antibacterial assay was performed by well diffusion method and identification of active compounds was analyzed by UV-Vis spectrophotometry and LC-MS/ MS. Extraction of the peel powder produced methanol extract, partition of the methanol extract resulted $\boldsymbol{n}$-hexane, ethyl acetate, $\boldsymbol{n}$-butanol, and water fractions. Antibacterial activity assay shows that ethyl acetate extract was the most active to inhibit the growth of both bacteria. Separation with column chromatography resulted 5 fractions. Identification of the most active fraction with $\mathrm{UV}$-Vis showed that the isolate gave maximum absorption at $\lambda 339.00 \mathrm{~nm}$ (band I) and $\lambda 262.00$ nm (band II) which were thought to be flavonol (3-OH substituted). Analysis with LC-MS/MS shows that the most active fraction contained 3-methacrylate flavonols and 3-(furan- 2yl) acrylate flavonols.
\end{abstract}

\section{Introduction}

Bacteria are prokaryotic microorganisms that do not have a nuclear membrane but still have genetic information in the form of DNA. Various kinds of bacteria often cause problems in the health, such as Staphylococcus aureus and Escherichia coli. Various clinical syndromes associated with diseases caused by $S$. aureus include skin and soft tissue infections, pneumonia, bone and joint infections, and central nervous system infections (Liu et al. 2011). While Diseases caused by $E$. coli include urinary tract infections, diarrhea, sepsis, and meningitis (Jawetz et al. 2008). Antibiotics are usually used to treat the infection, but the use of these has side effects, one of which is causing resistance. The resistance occurs due to inappropriate use of antibiotics and obstacles in developing new antibiotics (Ventola 2015). Prevention efforts are needed by controlling the use of antibiotics,

\footnotetext{
* Corresponding Author

E-mail Address: susanah.rita@unud.ac.id
}

developing research on resistance mechanisms, and developing new antibiotics both synthetic and natural (Liu et al. 2011).

The use of new antibiotics from natural ingredients continues to be developed. Samanea saman leaf $n$-butanol and ethanol extracts show antibacterial activity against $S$. aureus and E. coli (Rita et al. 2016; Rita et al. 2018). Samanea saman $n$-butanol extract also shows antifungal activity towards Candida albicans (Silaen 2020). Essential oils of Acorus calamus L. rizhome strongly inhibited the growth of $E$. coli and $S$. aureus (Rita et al. 2017a), and Candida albicans (Rita et al. 2017b). Antimicrobial activity against E. coli, S. aureus, and C. albicans was also shown by Acorus calamus L. rizhome ethanol extract (Susanah et al. 2018) and that of $n$-hexane, ethyl acetate, and $n$-butanol extracts (Rita et al. 2019). Ananta et al. (2018) reported that several kinds of local banana (Musa sp.) peels from Bali have antibacterial activity against E. coli and $S$. aureus. Wahyuni et al. (2019) revealed that yellow kepok banana peel (Musa Paradisiaca L.) $n$-butanol extract strongly inhibited the growth of $E$. coli and $S$. aureus 
with Minimum Inhibitory Concentrationa (MIC) was $0.5 \%$ for $S$. aureus and $0.2 \%$ for $E$. coli.

Banana is a very special fruit in Bali, because it is usually used as an offering in religious ceremonies. Banana fruit is usually consumed directly or used as raw material for food, but the peel is rarely used, even though the peel can be used as an ingredient in antibacterial drugs. Rita et al. (2020) reported antibacterial activity of selected local banana peels cultivated in Bali. Antibacterial assay on the peels against Staphylococcus aureus varied between 11.00 and $14.77 \mathrm{~mm}$ and that of Escherichia coli from 9.00 to $13.37 \mathrm{~mm}$ at concentration of $20 \%(\mathrm{~b} / \mathrm{v})$.

The activity of banana peel is due to the presence of secondary metabolites which synergize with one another. Ehiowemwenguan et al. (2014) stated that there were flavonoids, tannins, alkaloids, volatile oils, saponins, and glycosides in ethanol extract of Musa sapientum peels. Kibria et al. (2019) reported that secondary metabolites detected from banana peel (Musa paradisiaca) ethanol extract were flavonoids, tannins, saponins, alkaloids, and glycosides. Singh et al. (2016) reported that banana pulp and peel contained various phenolic compounds, such as gallic acid, catechin, epicatechin, tannins, and anthocyanins. According to Rita et al. (2020), banana peels from Bali contained phenolic compounds and flavonoids. Total phenolic contents varied between 177 and $276 \mathrm{mg} \mathrm{GAE} / 100 \mathrm{~g}$, while total flavonoid contents varied from 1756 to $2259 \mathrm{mg}$ QE/100g. Susanah et al. (2018) revealed that there was a positive correlation between antimicrobial activity and their flavonoid and phenolic contents.

We have conducted antibacterial assay to milk banana peels (Musa x paradisiaca L.) methanol extract against $E$. coli and S. aureus. The extract strongly inhibited $E$. coli and S. aureus with an inhibition of 17.50 and 10.25 $\mathrm{mm}$ at concentration of $25 \%$. Therefore, it is necessary to separate the compounds in the methanol extract to determine the structure of the compound, especially the flavonoid contained in the active fraction.

\section{Materials and Methods}

\subsection{Plant Material}

Milk banana peels were collected from Gianyar Bali. The fresh peels were cuti into small pieces and dried at room temperature for 3 weeks. The dried peels were powdered and used for extraction.

\subsection{Bacterial Agents}

Pure cultures of Staphylococcus aureus and Escherichia coli were purchased from the Laboratory of Clinical Microbiology of Region Public Hospital Sanglah Denpasar. The isolates were purified and maintained at $4^{\circ} \mathrm{C}$ until use.

\subsection{Extraction}

One kilogram of milk banana peel powder was macerated with $10 \mathrm{l}$ of methanol at room temperature $\left(25^{\circ} \mathrm{C}\right)$ for $2 \times 24 \mathrm{~h}$. The macerated extract was filtered through filter paper (Whatman No. 4) and evaporated under vacuum. The extracts were then stored at $4^{\circ} \mathrm{C}$ until further analysis. The methanol extract was then dissolved into methanol $70 \%$, then the methanol was evaporated to obtain a water extract. The water extract was then partitioned with $n$-hexane, ethyl acetate, and $n$-butanol respectively. The extracts were then evaluated their antibacterial activities.

\subsection{Antibacterial Activity Assay}

Antibacterial activity against Escherichia coli and Staphylococcus aureus was evaluated by well agar diffusion method (Rita et al. 2018 with modification). Antibacterial activity assay was carried out on the $n$-hexane, ethyl acetate, $n$-butanol, and water extracts with a concentration of $25 \%$, of which $10 \%$ tween as a negative control and $0.03 \%$ amoxicillin as a positive control. The extract $(20 \mu \mathrm{l})$ was put into each well which already contains bacteria $(200 \mu \mathrm{l})$, then incubated at $37^{\circ} \mathrm{C}$ for 24 hours. Inhibition zone (in diameter) was observed after incubation period. Then, the most active extract was performed with various concentrations. The concentration of extract applied were $0,1,2,3,4,5,10$, $15,25,50,75$, and $100 \%(\mathrm{w} / \mathrm{v})$. The assay was repeated in triplicate. Statistical analysis was performed using ANOVA test Duncan's Multiple Range Test. Minimum Inhibitory Concentration (MIC) was determined based on the lowest concentration of extract which still provides an inhibition zone.

\subsection{Separation of the Components in the Active Extract}

Separation was carried out by column chromatography. To determine the best mobile phase, a Thin Layer Chromatography (TLC) separation was performed previously with various eluents. The TLC plate that has been spotted the sample was inserted 
into the vessel that was saturated with mobile phase vapor in a vertical direction and allowed to elute until it reaches the predetermined limit mark. Then the TLC plate was removed and dried. The separation results were observed under a UV lamp at a wavelength of $254 \mathrm{~nm}$ and $366 \mathrm{~nm}$. The eluent which was capable of producing the most stain separation and well separated was the best mobile phase, it was used as a mobile phase in column chromatography.

Silica gel 60 was used as the stationary phase in column chromatography. One gram of the most active extract was dissolved with the solvent and fed into the column through the column wall. The mobile phase flow was speeded to $1 \mathrm{ml} /$ minute. The eluate obtained was collected every $3 \mathrm{ml}$. Eluates that have the same separation or stain pattern will be combined, then evaporated and tested for antibacterial activity.

\subsection{Identification Flavonoids of the Most Active Fraction}

The most active fraction was then phytochemically tested flavonoids and analyzed using Ultraviolet-Visible (UV-Vis) and Liquid chromatography-tandem mass spectrometry (LC-MS/MS) spectrometry.

The flavonoid test was carried out by addition 0.1 gram of magnesium powder and 5-6 drops of concentrated $\mathrm{HCl}$ into $1 \mathrm{ml}$ of the fraction (Wilstatter test), forming an orange to red color (Flavone), red to dark red (Flavanol), dark red to magenta (Flavanon) (Tiwari et al. 2011). If concentrated $\mathrm{HCl}$ is added (BateSmith test) then heated for 15 minutes on a water bath. If it gives a red color, it will positively contain flavonoids (Lestari et al. 2015). A few drops of diluted sodium hydroxide $(\mathrm{NaOH})$ solution was added to the fraction, yellow color was formed, and then additional with hardly any sulfuric acid made the colorless of fraction, expresses the existence of flavonoids (Sariwati et al. 2019).

UV-Vis spectrum measurements were carried out at a wavelength of 200-600 $\mathrm{nm}$. The most active fraction was dissolved with methanol to make a concentration of $0.01 \mathrm{mg} / \mathrm{ml}$ and its absorption was observed (Markham 1982).

The most active fraction was added to the reverse phase C18 pre-column (1.7 $\mu \mathrm{m} 2.1$ internal diameter x $20 \mathrm{~mm}$, BEH was separated by UPLC acetonitrile / $0.05 \%$ formic acid ( $\mathrm{v} / \mathrm{v})(\mathrm{A})$ and water + format acid (B). Elution was performed for 30 minutes at a rate of $0.2 \mathrm{ml} /$ minute). The elluent was then analyzed in an acquity UPLC * H Class System (water USA) quadrupole time of flight mass spectrometry (water USA) equipped with positive mode Electrospray ionization (ESI) source and operated using the xevo G2-s Qtof software. All mass spectra extracted using masslynx $v 4.1$ software.

\section{Results}

The results of the partition of the water extract (from $80 \mathrm{~g}$ of $70 \%$ methanol extract where methanol was evaporated) obtained $15.84 \mathrm{~g}$ of $n$-hexane extract, 8.30 $\mathrm{g}$ of ethyl acetate extract, $7.58 \mathrm{~g}$ of $n$-butanol extract, and of $5.70 \mathrm{~g}$ of water extract. Each extract was tested for its antibacterial activity against $S$. aureus and $E$. coli. Antibacterial activity assay was carried out at concentration of $25 \%$, of which $10 \%$ tween as a negative control and $0.03 \%$ amoxicillin as a positive control. The results of the assay can be seen in Table 1 .

Based on Table 1, it is known that the ethyl acetate extract of milk banana peel has the highest inhibitory zone in inhibiting the growth of $S$. aureus and E. coli, followed by $n$-butanol, water, and $n$-hexane extracts. water and $n$-hexane extract did not inhibit the growth of $E$. coli. therefore, the ethyl acetate extract was continued for antibacterial assay with various concentration and separation of the compounds by column chromatography.

The ethyl acetate extract antibacterial activity assay was carried out with various concentrations of $100,75,50,25,15,10,5,4,3,2$, and $1 \%$. The result of this assay is presented in Table 2. Meanwhile, Graph of the inhibitory zone of ethyl acetate extract against the growth of both bacteria is presented in Figure 1. These results indicate that the increase the extract concentration, the rise inhibitory zone of the both bacteria. Based on Table 2, it can be seen that the MIC of ethyl acetate extract in inhibiting S. aureus was $1 \%$ with a diameter of inhibition of $5.00 \mathrm{~mm}$, while the MIC in inhibiting E. coli was 3\% with an inhibitory

Table 1 . Results of antibacterial activity assay of $n$-Hexane, ethyl acetate, $n$-Butanol, and water extracts of milk banana peels against $S$. aureus and $E$. coli at concentration of $25 \%$

\begin{tabular}{lcc}
\hline \multirow{2}{*}{ Extracts } & \multicolumn{2}{c}{ Average inhibitory zone $(\mathrm{mm})$} \\
\cline { 2 - 3 } & S. aureus & E. coli \\
\hline n-Hexane & 6.0 & 0.0 \\
Ethyl acetate & 23.25 & 20.13 \\
n-Butanol & 13.25 & 9.75 \\
Water & 12.75 & 0 \\
Tween 10\% & 0 & 0 \\
Amoxicillin $0.03 \%$ & 31.50 & 25.25 \\
\hline
\end{tabular}


Table 2. Results of determination of bacterial growth inhibition of ethyl acetate extract against $S$. aureus and E. coli

\begin{tabular}{|c|c|c|}
\hline \multirow[t]{2}{*}{ Treatment (\%) } & \multicolumn{2}{|c|}{$\begin{array}{l}\text { The average inhibition zone of extracts } \\
\text { against bacteria }(\mathrm{mm})\end{array}$} \\
\hline & S. aureus & E. coli \\
\hline 0 & $0.00 \pm 0.00^{\mathrm{a}^{*}}$ & $0.00 \pm 0.00^{\mathrm{a}}$ \\
\hline 1 & $5.00 \pm 0.13^{b}$ & $0.00 \pm 0.00^{\mathrm{a}}$ \\
\hline 2 & $5.50 \pm 0.23^{c}$ & $0.00 \pm 0.00^{\mathrm{a}}$ \\
\hline 3 & $6.25 \pm 0.33^{\mathrm{d}}$ & $6.55 \pm 0.12^{\mathrm{b}}$ \\
\hline 4 & $6.38 \pm 0.14^{e}$ & $8.20 \pm 0.36^{c}$ \\
\hline 5 & $10.38 \pm 0.19^{f}$ & $10.25 \pm 0.11^{\mathrm{d}}$ \\
\hline 10 & $13.13 \pm 0.17^{g}$ & $13.25 \pm 0.27^{\mathrm{e}}$ \\
\hline 15 & $18.38 \pm 0.23^{\mathrm{h}}$ & $16.00 \pm 0.19^{\mathrm{f}}$ \\
\hline 25 & $23.25 \pm 0.47^{i}$ & $20.13 \pm 0.26^{g}$ \\
\hline 50 & $24.25 \pm 0.31^{\mathrm{j}}$ & $20.75 \pm 0.10^{\mathrm{h}}$ \\
\hline 75 & $25.25 \pm 0.40^{\mathrm{k}}$ & $21.38 \pm 0.13^{\mathrm{i}}$ \\
\hline 100 & $27.38 \pm 0.37^{1}$ & $22.38 \pm 0.11^{j}$ \\
\hline
\end{tabular}

*Different notations indicate significantly different values $(\mathrm{p}<0.05)$

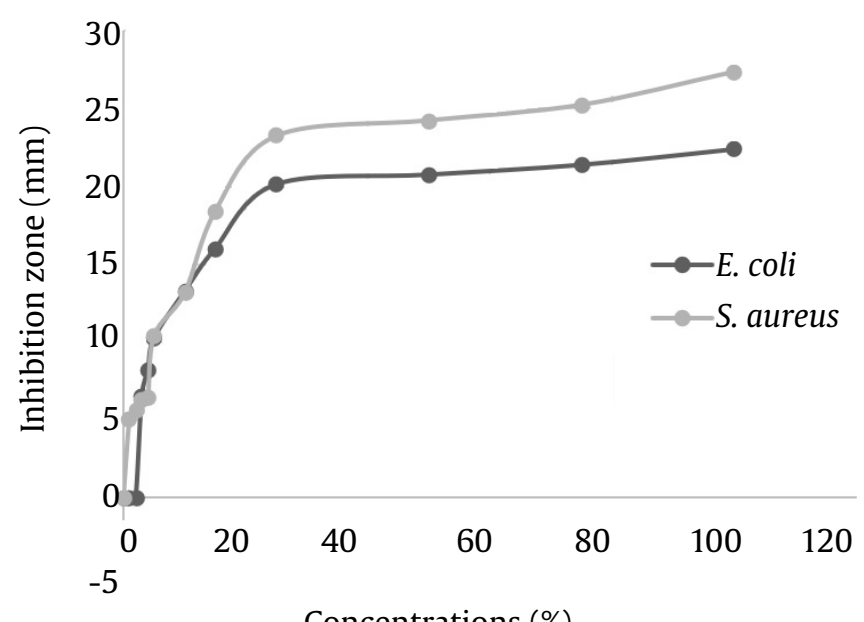

Figure 1. A curve of the inhibitory zone of ethyl acetate extract against the growth of S. aureus and E. coli

zone of $6.55 \mathrm{~mm}$. Based on the Duncan's Multiple Range Test, it appears that the treatment provided a significant difference between concentrations. From Figure 1 it can be seen that $S$. aureus was more sensitive than $E$. coli.

The selection of the best eluent for the separation of compounds by column chromatography was carried out using TLC with various mobile phases, including $n$-hexane: ethyl acetate (6.5: 3.5$), n$-hexane: ethyl acetate (7.5: 2.5 ), and chloroform: ethyl acetate (7.5:2.5) and used a stationary phase of silica gel GF254. The best eluent is an eluent that can separate compounds with a distance between the stains from each other quite far and produce the highest number of stains. The results of TLC are presented in Table 3. TLC results showed that chloroform: ethyl acetate (7.5:2.5) was the best eluent (mobile phase).

A total of 2.00 grams of ethyl acetate extract of milk banana was separated by column chromatography using $60 \mathrm{~g}$ of silica gel as a stationary phase and a mobile phase of chloroform: ethyl acetate (7.5:2.5). The result of separation obtained 200 bottles of eluate. Each eluate was tested by TLC to determine the separation pattern from column chromatography in which eluents having the same separation pattern were combined. Based on the stain pattern of each eluate, 6 fractions were produced which are presented in Table 4.

The six fractions resulted from column chromatography were assayed for their antibacterial activity against $S$. aureus and $E$. coli. The results of assay for antibacterial activity can be seen in Table 5 and Figure 2. The graph of comparison antibacterial

Table 3. Selection of the best eluent

\begin{tabular}{lcc}
\hline Eluent & Number of Stains & Rf value \\
\hline$n$-Hexane: ethyl & 8 & $0.02 ; 0.07 ; 0.13 ;$ \\
acetate $(6.5: 3.5)$ & & $0.20 ; 0.26 ; 0.39 ;$ \\
& & $0.48 ; 0.64$ \\
$n$-Hexane: ethyl & 8 & $0.04 ; 0.09 ; 0.14 ;$ \\
acetate $(7.5: 2.5)$ & & $0.24 ; 0.39 ; 0.47 ;$ \\
& & $0.55 ; 0.95$ \\
Chloroform: ethyl & \multirow{2}{*}{9} & $0.06 ; 0.14 ; 0.21 ;$ \\
acetate (7.5:2.5) & & $0.35 ; 0.49 ; 0.65 ;$ \\
& & $0.74 ; 0.87 ; 0.92$ \\
\hline
\end{tabular}

Table 4. TLC results from column chromatography

\begin{tabular}{clcll}
\hline Fractions & Colour & $\begin{array}{l}\text { The number } \\
\text { of Stains }\end{array}$ & Rf value & $\begin{array}{c}\text { Weight } \\
(\mathrm{g})\end{array}$ \\
\hline 1 & yellow & 2 & $0.15 ; 0.95$ & 0.0360 \\
2 & Orange & 1 & 0.81 & 0.0057 \\
3 & Red & 4 & $0.28 ; 0.53 ; 0.74$ & 0.1113 \\
4 & Red & 5 & $0.06 ; 0.18 ; 0.66$ & 0.1038 \\
5 & Orange & 2 & $0.24 ; 0.88$ & 0.0632 \\
& redness & & & \\
6 & Orange & 2 & $0.27 ; 0.41$ & 0.0624 \\
\hline
\end{tabular}

Table 5. Results of antibacterial activity assay of column fraction on the growth of S. aureus and E. coli

\begin{tabular}{lcr}
\hline \multirow{2}{*}{ Fractions } & \multicolumn{2}{c}{ The average of inhibition $(\mathrm{mm})$} \\
\cline { 2 - 3 } & S. aureus & E. coli \\
\hline F1 & 9.00 & 10.30 \\
F2 & 9.75 & 8.25 \\
F3 & 20.00 & 11.75 \\
F4 & 30.38 & 20.25 \\
F5 & 37.25 & 27.38 \\
F6 & 25.88 & 21.63 \\
\hline
\end{tabular}



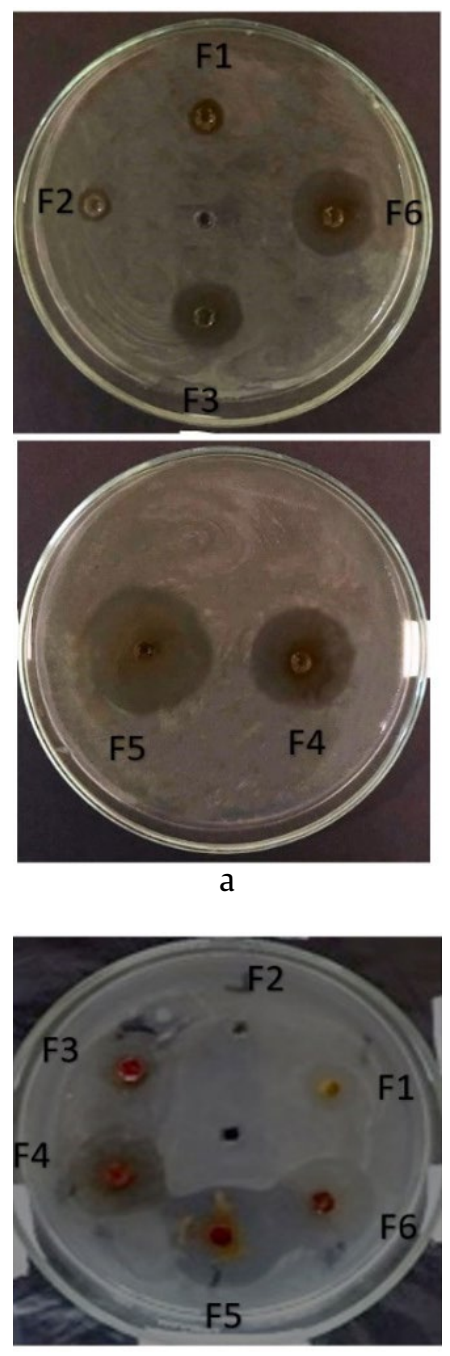

b

Figure 2. Antibacterial assay results for the fraction of the column chromatography against (a) S. aureus and (b) E. coli

activity of the fractions between $S$. aureus and $E$. coli is presented in Figure 3. Based on the results of the antibacterial assay, it can be seen that fraction 5 (F5) was the most active fraction to inhibit both S. aureus and E. coli, followed by F6, F4, F5, F1, and F2 respectively. However, the inhibition against $S$. aureus was higher than that of $E$. coli.

Based on the phytochemical test, it was estimated that the F5 contained the flavonol group which were indicated by formation of a red color with Wilstatter reagent, an orange color with Bate-Smith reagent, and a yellow color with $\mathrm{NaOH}$ solution. The F5 was then identified using a UV-Vis and LC-MS/MS spectrophotometer.

The results of the analysis with a UV-Vis spectrophotometer for F5 can be seen in Figure 4 .

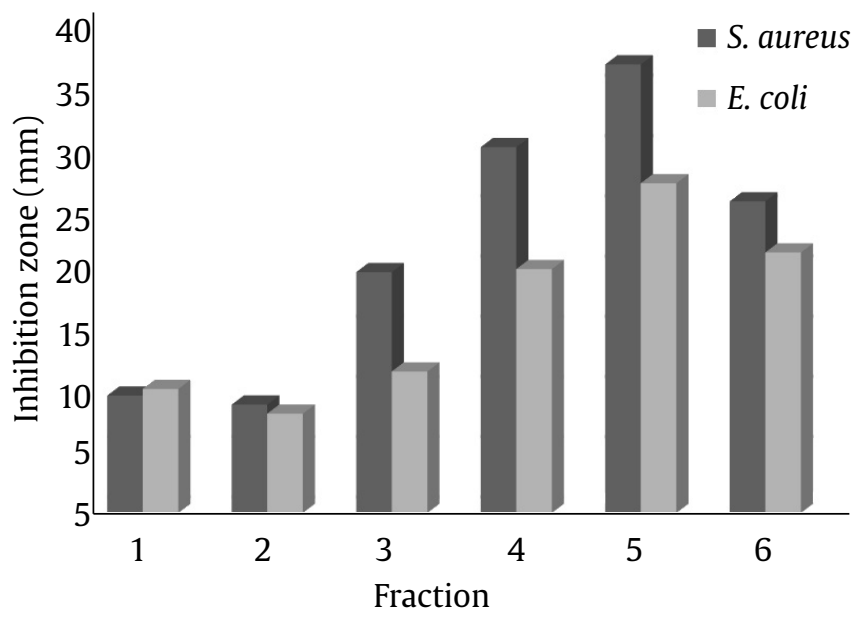

Figure 3. The graph of comparison antibacterial activity of the fractions between S. aureus and E. coli

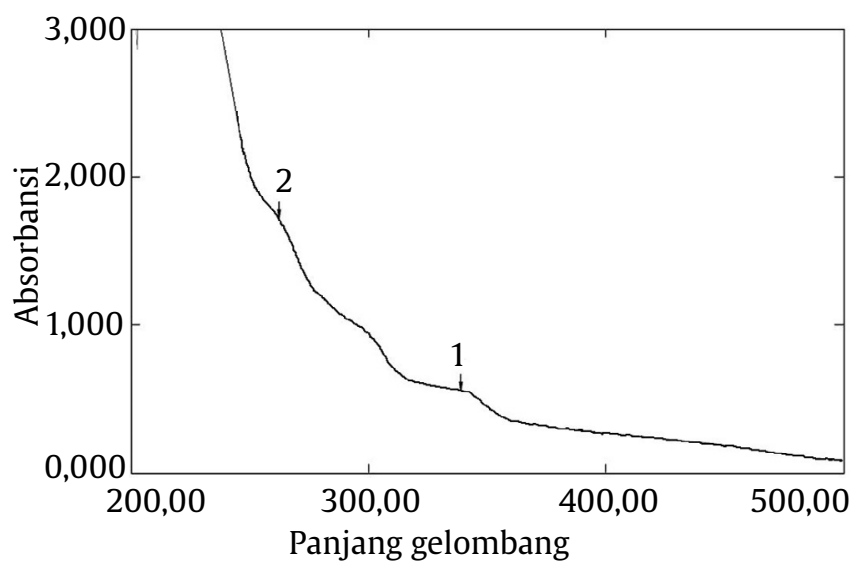

Figure 4. UV-Vis spectrum of F5

Based on the Figure, there were two absorption bands which were characteristic of flavonoids. The chromatogram pattern of F5 analysis using LC-MS/ MS showed that there were peaks in the retention times of 8.462 and 9.125 which were thought to be flavonoids (substituted 3-OH). Mass spectrum of F5 with LC-MS/MS ESI positive ion at a retention time of 8.462 and 9.125 are presented in Figure 5 and 6 . The results of LC-MS/MS analysis of F5 fraction and the suspected compounds can be seen in Table 6. The MS/MS spectrums are shown in Figures 5. Flavonoids that were in the active fraction were thought to be a flavonol group with the name of 3-methacrylate flavonols and 3-(furan-2il) acrylate flavonols (Figure 7).

\section{Discussion}

The solvents used in the partition process are based on the degree of polarity, starting with the 


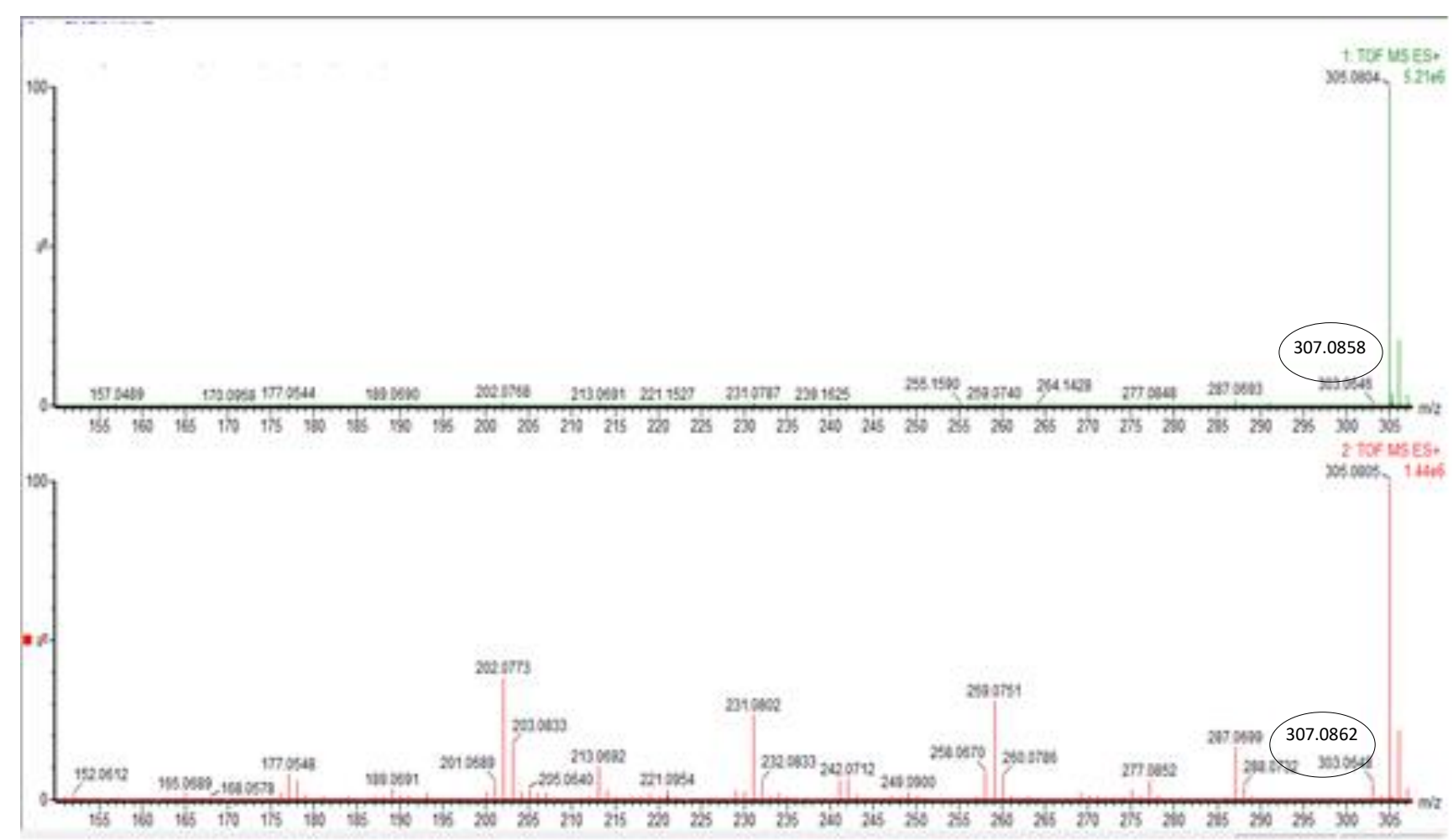

Figure 5. Mass spectrum of F5 with LC-MS/MS ESI positive ion at a retention time of 8.462

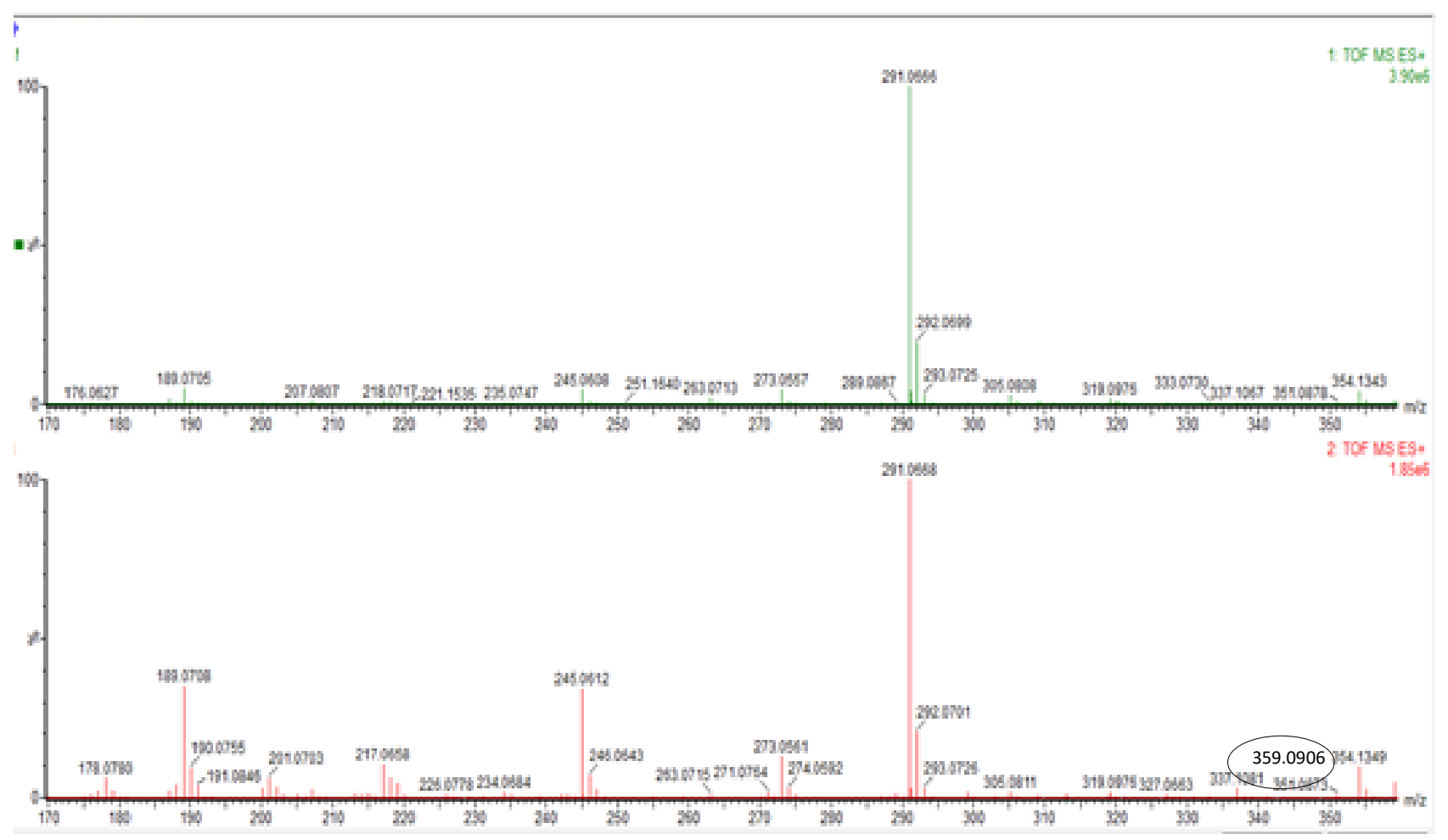

Figure 6. Mass spectrum of F5 with LC-MS/MS ESI positive ion at a retention time of 9.125 
Table 6. Results of LC-MS/MS analysis of fraction 5 and suspected compounds

\begin{tabular}{llll}
\hline $\begin{array}{l}\text { Retention } \\
\text { time (Rt) }\end{array}$ & \multicolumn{2}{c}{$\mathrm{m} / \mathrm{z}(\mathrm{M}+\mathrm{H})$} & $\begin{array}{l}\text { Suspected } \\
\text { compounds }\end{array}$ \\
\cline { 2 - 4 } & $\begin{array}{l}\text { Precursor } \\
\text { ion }\end{array}$ & $\begin{array}{l}\text { Product } \\
\text { ion }\end{array}$ & \\
\hline 8.462 & 307.0862 & $\begin{array}{l}305.0805 \text { (peak } \\
\text { ion); } 287.0669 ;\end{array}$ & $\begin{array}{l}\text { 3-methacrylate } \\
\text { flavonols }\end{array}$ \\
& & $259.0751 ;$ & \\
& & $231.0802 ;$ & \\
9.125 & & 177.0548 & \\
& 359.0906 & $305.0811 ;$ & 3-(furan-2il) \\
& & 291.0668 (peak & acrylate \\
& & ion); 263.0715; & flavonols \\
& & 235.0748 & \\
\hline
\end{tabular}

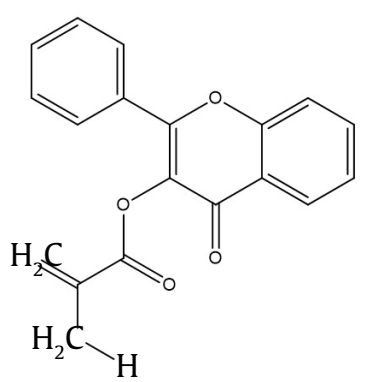

(1)

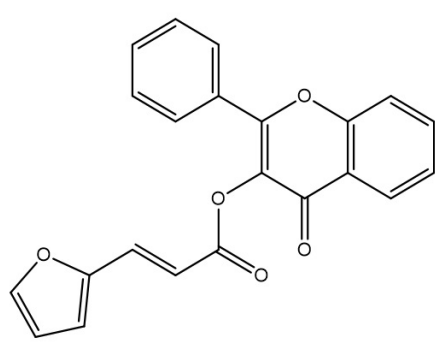

(2)
Figure 7. Estimated structure of compounds from LC-MS/S analysis (1) 3-methacrylate flavonol (tR 8,462) and (2) 3-(furan-2il) acrylate flavonol (tR 9,125)

non-polar solvent ( $n$-hexane), followed by semipolar (ethyl acetate) and polar (n-butanol). One of the semi-polar groups of compounds is flavonoids which are not bound by sugar. This was in accordance with the research of Rita et al. (2019) who conducted an antibacterial test on the partition extract from the rhizome of Acorus calamus.

The results of the antibacterial activity assay showed that the ethyl acetate extract of milk banana peels was the most active in inhibiting the growth of $S$. aureus and $E$. coli. This shows that the antibacterial compounds in the peels were semipolar compounds. Tamokou et al. (2012) reported that ethyl acetate extract, fractions and compounds from stem bark of Albizia adianthifolia (Mimosoideae) showed antimicrobial activity against some bacteria and yeasts. Saeidi et al. (2014) revealed that ethyl acetate and aqueous extracts of Mentha longifolia L. have antibacterial activity against important human pathogens. Keikhaie et al. (2018) also reported that MIC of ethyl acetate Extract of Securigera securidaca, Withania sominefra, Rosmarinus officinalis, and Aloe vera Plants was lower than that of Methanol extract against Important Human Pathogense. This means that the ethyl acetate extract was more active than the methanol extract.

When compared to the inhibition zone of methanol extract, ethyl acetate extract produced a higher inhibitory zone. This is probably because the compounds contained in methanol extract were antagonistic. The methanol extract was the result of the maceration process where there were still a lot of compounds from polar to nonpolar. So that the ethyl acetate extract that has gone through the separation process produced a higher inhibition. Antibacterial assay which was carried out with various concentrations showed a positive correlation of the inhibitory zone of the extracts against the bacteria with the applied extract concentration. in addition, based on Duncan's test it was found that the inhibition was significantly different between the concentrations applied. This is in line with the studi Susanah et al. (2018) which states that the concentration of the extract applied affected the inhibition of bacterial growth, and changes in concentration have a significant effect on the inhibition. The MIC of ethyl acetate extract in inhibiting $S$. aureus was $1 \%$ with a diameter of inhibition of $5.00 \mathrm{~mm}$, while the MIC in inhibiting $E$. coli was $3 \%$ with an inhibitory zone of $6.55 \mathrm{~mm}$. MIC was determined based on the lowest concentration of extract which still provides an inhibition zone. Therefore, the lower the MIC, the greater the activity in inhibiting bacteria (Keikhaie et al. 2018; Mogana et al. 2020; Panphut et al. 2020). Balouiri et al. (2016) revealed that the method to determine antibacterial can be various, one of them is by diffusion method. This method can be used either to determine the inhibition zone, MIC or otherwise.

Antibacterial activity assay of fractions from separation with chromatography column shows that the fifth fraction (F5) produced the highest inhibition zone among the other fractions with an inhibition diameter of $37.25 \mathrm{~mm}$ which was included in the very strong category. The diameter of the inhibition zone produced by $\mathrm{F} 5$ fraction was greater than the diameter of the inhibition zone of ethyl acetate extract. This was because the compounds contained in ethyl acetate extract were antagonistic each other, so that they were more active as antibacterial in an individual or single form. In general, S. aureus (gram positive bacteria) was more sensitive than $E$. coli (gram negative bacteria). This is due to differences in 
the cell wall complexities of the both bacteria (Pelczar 2002). E. coli contains peptidoglycan between the inner and outer membranes, and the outer membrane was derived from lipopolysaccharides, proteins, and lipids. Polysaccharides have a role in prevent the entry of hydrophobic compounds into cell membranes, whereas lipids played a role in preventing entry hydrophilic compound (Prescott et al. 2002; Pelczar et al. 2002).

Based on the phytochemical test, it is known that the $\mathrm{F} 5$ fraction contained flavonoid compounds of the flavonol group (Tiwari et al. 2011). The mass spectrum in Figure 5 with a retention time of 8,462 , detected the peak of the precursor ion with $(\mathrm{M}+\mathrm{H})^{+}$ $307.0862\left(\mathrm{C}_{19} \mathrm{H}_{15} \mathrm{O}_{4}\right)$ and the product ion at $\mathrm{m} / \mathrm{z}$ $305.0805\left(\mathrm{C}_{19} \mathrm{H}_{13} \mathrm{O}_{4}\right)$ (peak ion), $287.0669\left(\mathrm{C}_{19} \mathrm{H}_{11} \mathrm{O}_{3}\right)$, $259.0751\left(\mathrm{C}_{18} \mathrm{H}_{11} \mathrm{O}_{2}\right), 231.0802\left(\mathrm{C}_{17} \mathrm{H}_{11} \mathrm{O}\right), 177.0548$ $\left(\mathrm{C}_{13} \mathrm{H}_{5} \mathrm{O}\right)$ identified as 3-methacrylate flavonols. The mass spectrum in Figure 6 with a retention time of 9,125 , detected the peak of the precursor ion with $(\mathrm{M}+\mathrm{H})^{+} 359.0906\left(\mathrm{C}_{22} \mathrm{H}_{14} \mathrm{O}_{5}\right)$ and the product ion at $\mathrm{m} / \mathrm{z} 305.0811\left(\mathrm{C}_{19} \mathrm{H}_{13} \mathrm{O}_{4}\right), 291.0668\left(\mathrm{C}_{18} \mathrm{H}_{11} \mathrm{O}_{4}\right)$ (peak ion), $263.0715\left(\mathrm{C}_{16} \mathrm{H}_{7} \mathrm{O}_{4}\right), 235.0748\left(\mathrm{C}_{15} \mathrm{H}_{7} \mathrm{O}_{3}\right)$ identified 3-(furan-2il) acrylate flavonols.

Based on identification using LC-MS/MS, it is known that the active compound at $F 5$ which plays an active role as an antibacterial against $S$. aureus and $E$. coli was thought to come from the flavonol compound, namely 3-methacrylate flavonols and 3-(furan-2il) acrylate flavonols. This was also supported by the results of phytochemical tests and analysis with UVVis which show that the compounds contained in F5 were flavonoids in the flavonol group. Asih et al. (2018) also succeeded in identifying flavonoid glycoside compounds in the flavonol (3-OH substituted) group from the $n$-butanol extract of tamarillo, namely routine, quercetin 3-O rhamnoside, and kaemferol 3-O routineoside. According to Rita et al. (2016) activity of flavonoids and phenols as antibacterials is caused by the formation of complexes with bacterial proteins through hydrogen bonds, covalent bonds and hydrophobic bonds, so as to deactivate enzymes from bacteria.

\section{Acknowledgements}

This research was funded by the Director General of Higher Education through the Grand Research
Basic Higher Education Research. On this occasion, the author would like to thank the Institute for Research and Community Service Udayana University for facilitating everything related to this research.

\section{References}

Ananta IGBT et al. 2018, Potential of local banana peel waste extract (Musa sp.) as antibacterial against Escherichia coli and Staphylococcus aureus. Cakra Kimia 6:21-29.

Asih IARA et al. 2018. The flavonoid glycosides antioxidant from terong Belanda (Solanum betaceum). Biomedical and Pharmacology Journal 11:2135-2141.

Balouiri $\mathrm{M}$ et al. 2016. Methods of in vitro evaluating antimicrobial activity: a review. Journal of Pharmaceutical Analysis 6:71-79.

Ehiowemwenguan $\mathrm{G}$ et al. 2014. Antibacterial and phytochemical analysis of Banana fruit peel. IOSR Journal of Pharmacy 4:18-25.

Jawet E et al. 2016. Medical Microbiology. 27th ed. New York: McGraw-Hill Publisher.

Keikhaie KR et al. 2018. Antibacterial activity of ethyl acetate and methanol extracts of Securigera securidaca, Withania sominefra, Rosmarinus officinalis and Aloe vera Plants against Important Human Pathogens. Journal of Medical Bacteriology 7:13-21.

Kibria AA et al. 2019. Extraction and evaluation of phytochemicals from banana peels (Musa sapientum) and banana plants (Musa paradisiaca). Malaysian Journal of Halal Research Journal 2:22-26.

Lestari MS et al. 2015. Toxicity and phytochemistry test of methanol extract of several plants from papua using Brine Shrimp Lethality Test (BSLT).Journal of Chemical and Pharmaceutical Research 7:866-872.

Liu C et al. 2011. Clinical practice guidelines by the infectious diseases society of America for the treatment of methicillin-resistant Staphylococcus aureus infections in adults and children: executive summary. Clinical Infectious Diseases 52:285-292.

Markham KR. 1982. Techniques of Flavonoid Identification. USA: Academic Press.

Mogana R et al. 2020. Antibacterial activities of the extracts, fractions and isolated compounds from Canarium patentinervium Miq. against bacterial clinical isolates. BMC Complementary Medicine and Therapies 20:1-11.

Panphut $\mathrm{W}$ et al. 2020. In vitro antimicrobial activity of Piper retrofractum fruit extracts against microbial pathogens causing infections in human and animals. International Journal of Microbiology 2020:1-6.

Pelczar MJ et al. 2002. Microbiology. 5th Ed. New Delhi: Tata Mc Graw Hill.

Prescott LM et al. 2002. Microbiology: Food and Industrial Microbiology. 5th Ed. Boston: McGraw-Hill.

Rita WS et al. 2016. Total Flavonoid and Phenolic Contens of $n$-butanol extract of Samanea saman Leaf and The Antibacterial Activity Towards Escherichia coli and Staphylococcus aureus. In: 5th International Conference and Workshop on Basic and Applied Sciences (ICOWOBAS 2015). Surabaya: AIP Conference Proceedings. pp. 1-6.

Rita WS et al. 2017a. Antibacterial activity of Acorus calamus Linn. rhizome essential oil against Escherichia coli and Staphylococcus aureus. Cakra Kimia (Indonesian E-Journal of Applied Chemistry) 5:130-136.

Rita WS et al. 2017b. The essential oil contents of Jeringau (Acorus calamus L.) rhizome and their antifungal activity against Candida albicans. Journal of Health Sciences and Medicine 1:33-38. 
Rita WS et al. 2018. Antibacterial activity of Samanea Saman leaf ethanol extract against Escherichia coli and Staphylococcus aureus and Its total flavonoid and phenolic contents. Journal of Chemistry 12:121-127.

Rita WS et al. 2019. Antimicrobial Activity of Acorus calamus L. Rhizome Extract and Its Total Flavonoid and Phenolic Contents. In: Proceedings of the 2nd International Conference on Biosciences and Medical Engineering (ICBME2019). Denpasar: AIP Conference Proceeding. pp. 1-9.

Rita WS et al. 2020. Antibacterial activity and antioxidant capacity of selected local banana peel (Musa sp.) methanol extracts cultivated in Bali. International Journal of Agriculture, Environment and Bioresearch 5:242-251.

Saeidi S et al. 2014. Antibacterial activity of ethyl acetate and aqueous extracts of Mentha longifolia L. and hydroalcoholic extract of Zataria multiflora Boiss. plants against important human pathogens. Asian Pacific Journal of Tropical Medicine 7:86-189.

Sariwati S et al. 2019. Phytochemical, antibacterial and antioxidant activities of Anthurium hookerii leaves Extracts. HAYATI Journal of Biosciences 26:101-109.

Singh BS et al. 2016. Bioactive compounds in banana and their associated health benefits- a review. Food Chemistry 206:1-11.
Silaen AD et al. 2020. Antifungal activity of $n$-butanol extract from Trembesi (Albizia saman (Jacq.) Merr) leaves against Candida albicans and determination of total flavonoids. Cakra Kimia (Indonesian E-Journal of Applied Chemistry) 8:9-15.

Susanah RW et al. 2018. Total Phenolic and flavonoid contents and antimicrobial activity of Acorus calamus L. rhizome ethanol extract. Research Journal of Chemistry and Environment 22:65-70.

Tamokou JD et al. 2012. Antioxidant and antimicrobial activities of ethyl acetate extract, fractions and compounds from stem bark of Albizia adianthifolia (Mimosoideae). BMC Complementary and Alternative Medicine 12:1-10.

Tiwari P et al. 2011. A review: phytochemical screening and extraction. Internationale Pharmaceutica Sciencia $1: 98-106$

Ventola CL. 2015. The antibiotic resistance crisis part 1: causes and threats. Journal Pharmacy and Therapeutics 40:277-283.

Wahyuni NKDMS et al. 2019. Antibacterial activity of yellow Kepok banana peel extract (Musa Paradisiaca L.) against Staphylococcus aureus and Escherichia coli and determination of total flavonoids and phenols in active fractions. Journal of Chemistry 13:9-16. 